\title{
Early Detection of Diabetic Retinopathy through Machine Learning Techniques
}

\author{
Manjula L, G T Raju
}

\begin{abstract}
Diabetic Retinopathy $(D R)$ is progressive syndrome that leads to loss of vision if not detected and treated. Retina is inner tunic of the eyeball which is capillary and delicate transparent membrane. It is high developed tissue of eye which plays a major role for vision. Retina is the source for detection of many disorders. Part of retina with optic disc can be viewed through optamoloscope and termed as fundus image which is a basis of diagnosis for DR. DR can be categorized as Proliferative Diabetic Retinopathy (PDR), Diabetic Maculopathy, Nonproliferative Diabetic Retinopathy (NPDR) and Advanced Diabetic Eye Disease. Machine Learning (ML) techniques play a vital role in early detection of $D R$. In this paper a review on the existing techniques with open issues to be addressed is presented for diagnosing $D R$ and model is proposed to consider the features namely Microaneurysms, Retinal Hemorrhages, Hard exudates, Cotton wool Spots, Neovascularization for classification of DR. These features can be combined with hypertension to predict other disorders like stroke, chronic heart disease, renal dysfunction, cardiovascular mortality and so on which overcome the need of other preliminary checkup.The complete profile of disorders for a diabetic patient can be deduced by the retinal fundus image.
\end{abstract}

Keywords: Diabetic Retinopathy, Machine Learning, Retinal Fundus Images.

\section{I.INTRODUCTION}

$\mathrm{R}$ Retina is the innermost tunic of eyeball and the only part of Central Nervous System which can be viewed through optamoloscope. Retina contains light sensitive cells in the eyes, driving from neural tube which is derived from optic cup in turn from optic vesicle. Optical vesicle originates from diencephalon which imparts sensory information connecting brain regions in turn control several autonomic functions of peripheral nervous system. So Retina is the source for detection of many disorders.

Retina comprises of two distinct regions namely Posterior Pole and Peripheral Retina. The Posterior pole of the retina includes the Optic Disc and Macula Lutea which can be viewed through fundus images. Optic Disc is vascular and Macula Lutea is avacular.

Fundus images are the source for diagnosis of many vascular disorders of retina namely Retinal occlusions, Diabetic Retinopathy (DR), Hypertensive Retinopathy, Retinopathy of prematurity, Cardio vascular Risk, Stroke and so on. Early diagnosis is the key to slow down the progression of these diseases.

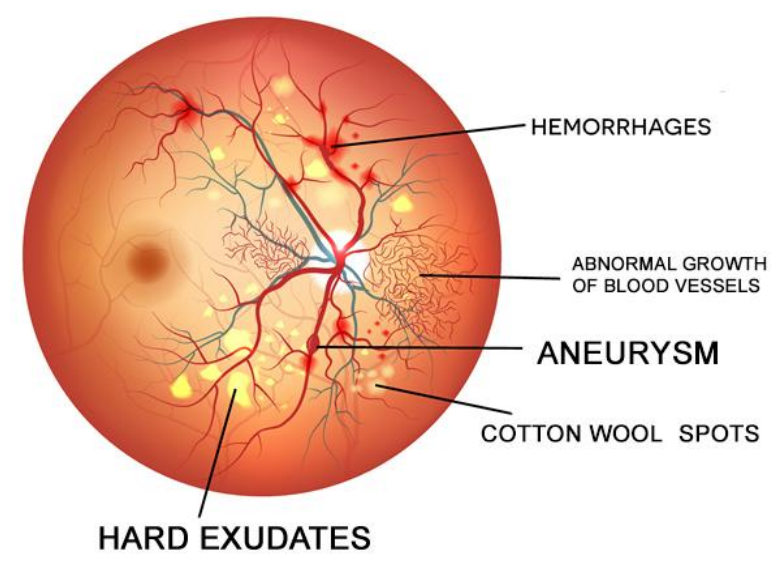

Fig. 1. Retina with DR features

DR is one of the major causes for loss of vision which refers to a retinal changes seen in patients with Diabetic Mellitus (DM) and the features are as shown in figure 1. Earlier detection is a key factor to prevent loss of vision for people with DM. The longer a person with DM has higher chance of developing DR. Other Risk factors include Heredity, Hypertension, Smoking, Obesity, Anemia and Hyperlipidaemia.

\section{CLASSIFICATION OF DIABETIC RETINOPATHY}

Hyperglycemia with uncontrolled DM is starting point of the development of DR [9]. Hyperglycemia is the increased levels of glucose in blood which leads to Microangiopathy (small vessel disease) which affects pre-capillary arterioles, capillaries and venules are the basic pathology in diabetic retinopathy. Effects of Microangiopathy producing DR include:

- Breakdown of Blood -Retinal Barrier: Retinal Oedema, Hemorrhages and leakage of lipids (hard Exudates).

- Weakened Capillary Wall: Aneurysms and Hemorrhages.

- Micro vascular Occlusions: Produce ischemia which is the limit in blood supply to the tissues, causing a lack of oxygen that is preferred for cellular metabolism) and arteriovenous shunts (intra retinal micro vascular abnormalities) 
DR has been variously classified as shown in figure 2 :

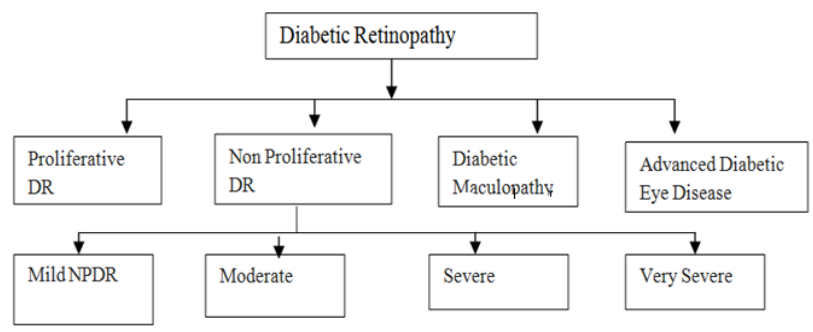

Fig. 2. Classification of DR

\section{A.Non-Proliferative Diabetic Retinopathy:}

NPDR is common in Type 2 DM patients. They are identified by Microaneurysms, Retinal Hemorrhages, Retinal oedema, hard exudates, Venous Abnormalities, Cotton wool Spots, Intraretinal micro vascular abnormalities. NPDR is further classified as:

- Mild NPDR- One Microaneurysms atleast must be there.

- Moderate NPDR- Microneurysms/interretinal hemorrhages in 2 or 3 quadrants, early mild Intraretinal Microvascular Abnormality (IRMA), arduous or fleecy exudates may be or not be present.

- Severe NPDR- 4-2-1 Rule i.e. Four Quadrants of Microaneurysms and extensive internal hemorrhages, Two quadrants of venous bleeding and One quadrant of IRMA changes. In which anyone of 4-2-1 is present.

- Very Severe- 4-2-1 Rule in which any two of them is present.

\section{B.Proliferative Diabetic Retinopathy:}

PDR develops with many of $50 \%$ cases after about 20 years of onset of the DM. Juvenile onset diabetes patients are more prone. Occurrence of neo vascularization at optic disk or elsewhere is the hallmark of PDR. Neo vascularization is referred to as a state in which firm pathologic vessels originates from the active retinal veins and widen along the interior surface of retina. Later on results in the formation of Fibrovascularnepiretinal membrane or vitreous hemorrhage and vitreous detachment.

\section{C.Diabetic Maculopathy:}

It refers to changes in Macular region and adversely affects the vision. It involves thickening of retina or arduous exudates at or within the 500 micron of Fovea.

\section{D.Advanced Diabetic Eye Disease:}

It is the anarchic PDR. It is noticeable by complications such as continual vitreous hemorrhage, Tractional retinal separation and Neo vascular Glaucoma.

Earlier detection of DR does not involve Advanced Diabetic Eye disease as it is final stage for vision loss.

\section{MACHINE LEARNING TECHNIQUES}

ML is programing computing device to improve a performance measure by using example data or by past experience. They are broadly categorized into Unsupervised, Supervised and Reinforcement learning. ML approaches are applied to many fields in which health applications have an extensive benchmark. Diagnosis of DR is a major yardstick.

\section{A.Supervised Learning:}

Supervised methods have great importance for medical image classification. Supervised ML is a task of data acquisition function that corresponds input to output supported on pattern input-output twain. It infuses a task from the labeled training data which consists of examples of training set.

Supervised ML algorithms include grouping and regression. When the outputs are confined to limited primed of values classification algorithms are used. Some of the approaches for diagnosis of DR are tabulated as shown in Table-I.

As deduced in the table-I, the CNN (Convolution Neural Network) is considered as the best approach for multiple feature selection and for classification, $\mathrm{CNN}$ or any other ML techniques can be used.

\section{B.Unsupervised Learning:}

Unsupervised Learning uses the unlabeled data where the training set is not provided. So the common diagnostic features are considered among them by organizing the data, searching and changing supported on internal knowledge. Algorithm tries to place related things in a cluster and non related in a different cluster. The idea of similarity is infered from the similarity measure. Some of the approaches for diagnosis of DR are tabulated as shown in Table-II.

The table I and II present different machine learning approaches. The open challenges to be addressed are:

- Multi-Feature Selection namely Microaneurysms, Retinal, Hemorrhages, Retinal oedema, Cotton woolen Spots, Arduous exudates, Venous Retardation, Intraretinal micro vascular abnormalities is a challenging task.

- The different classification techniques PDR, NPDR and Diabetic Maculopathy.

- The Performance and time efficient method selection for the feature extraction and classification. 
Table- I: Supervised learning Techniques to diagnose DR

\begin{tabular}{|c|c|c|c|c|c|c|c|c|c|}
\hline \multirow{3}{*}{$\begin{array}{l}\text { Authors/ } \\
\text { Referenc } \\
\text { e } \\
\text { Handayani } \\
\text { Tjandrasa } \\
\text { [3], 2013 }\end{array}$} & \multirow{3}{*}{$\begin{array}{l}\text { Approach } \\
\text { Soft } \\
\text { Margin } \\
\text { SVM }\end{array}$} & \multirow{3}{*}{$\begin{array}{l}\text { Data Set } \\
\text { Messidor } \\
\text { database }\end{array}$} & \multirow{3}{*}{$\begin{array}{l}\text { Classification } \\
\text { 1. Moderate } \\
\text { NPDR } \\
\text { 2. Severe } \\
\text { NPDR }\end{array}$} & \multirow{3}{*}{$\begin{array}{l}\text { Classification } \\
\text { Parameters } \\
\text { Hard Exudates }\end{array}$} & \multicolumn{3}{|c|}{ Performance Measures } & \multirow{3}{*}{$\begin{array}{l}\text { Merits } \\
\text { Improved speed } \\
\text { with high } \\
\text { accuracy }\end{array}$} & \multirow{3}{*}{$\begin{array}{l}\text { Demerits } \\
\text { NPDR is } \\
\text { constructed } \\
\text { only based } \\
\text { on exudates } \\
\text { features. }\end{array}$} \\
\hline & & & & & Specificity & Sensitivity & $\begin{array}{l}\text { Accurac } \\
\mathrm{y}\end{array}$ & & \\
\hline & & & & & - & - & $90.54 \%$ & & \\
\hline $\begin{array}{l}\text { Jayant } \\
\text { Yadav } \\
{[4], 2017}\end{array}$ & $\begin{array}{l}\text { Feed } \\
\text { forward } \\
\text { Neural } \\
\text { Network }\end{array}$ & & $\begin{array}{l}\text { 1. DR } \\
\text { 2. Non-DR }\end{array}$ & $\begin{array}{l}\text { 1. Normal } \\
\text { 2. Dot } \\
\text { hemorrhages } \\
\text { 3. Exudates } \\
\text { 4. Both }\end{array}$ & - & - & $75 \%$ & $\begin{array}{l}\text { Optimized } \\
\text { resource } \\
\text { requirements. }\end{array}$ & $\begin{array}{l}\text { Accuracy is } \\
\text { minimal }\end{array}$ \\
\hline $\begin{array}{l}\text { ShuangYu } \\
{[5], 2017}\end{array}$ & $\mathrm{CNN}$ & $\begin{array}{l}\text { E-Ophtha } \\
\text { EX }\end{array}$ & $\begin{array}{l}\text { 1. DR } \\
\text { 2. Non-DR }\end{array}$ & $\begin{array}{l}\text { Pixel level } \\
\text { Exudates } \\
\text { detection }\end{array}$ & $96 \%$ & $88.85 \%$ & $91.92 \%$ & $\begin{array}{l}\text { Fair } \\
\text { generalization } \\
\text { capability even } \\
\text { with varying } \\
\text { the contrast and } \\
\text { image quality. }\end{array}$ & $\begin{array}{l}\text { Considers } \\
\text { only exudates } \\
\text { feature. }\end{array}$ \\
\hline $\begin{array}{l}\text { Devvi } \\
\text { Sarwinda } \\
\text { [7], } 2018\end{array}$ & $\begin{array}{l}\text { SVM and } \\
\text { Random } \\
\text { Forest } \\
\text { learning }\end{array}$ & DiaretDB0 & $\begin{array}{l}\text { 1. Normal } \\
\text { 2. Mild-NPDR } \\
\text { 3. Moderate- } \\
\text { NPDR } \\
\text { 4. Severe- } \\
\text { NPDR } \\
\end{array}$ & $\begin{array}{l}\text { Texture } \\
\text { analysis }\end{array}$ & - & $91 \%$ & $85 \%$ & $\begin{array}{l}\text { Features are } \\
\text { extracted from } \\
\text { HOG method } \\
\text { where no } \\
\text { explicit training } \\
\text { is required }\end{array}$ & $\begin{array}{l}\text { Constrained } \\
\text { only for } \\
\text { NPDR }\end{array}$ \\
\hline $\begin{array}{l}\text { Maroof } \\
\text { Ahmad } \\
{[8], 2019}\end{array}$ & $\begin{array}{l}\text { DEEP } \\
\text { LEARNIN } \\
\text { G }\end{array}$ & $\begin{array}{l}\text { Messidor-2 } \\
*\end{array}$ & $\begin{array}{l}\text { 1. NPDR } \\
\text { 2. Normal } \\
\text { 3. (PDR) }\end{array}$ & $\begin{array}{l}\text { 1. Micro } \\
\text { aneurysms } \\
\text { 2. Hard } \\
\text { exudates } \\
\text { 3. Hemorrhages } \\
\text { 4. Neo- } \\
\text { Vascularisation }\end{array}$ & - & - & $\begin{array}{l}0.90- \\
0.95(\mathrm{Gr} \\
\text { anular } \\
\text { level ) } \\
0.20- \\
0.45 \\
\text { (Avera } \\
\text { ge } \\
\text { Localiz } \\
\text { ation) }\end{array}$ & $\begin{array}{l}\text { 1. Eliminates } \\
\text { the need for } \\
\text { feature } \\
\text { selection } \\
\text { explicitly } \\
\text { designed } \\
2 . \\
\text { Classification } \\
\text { performance is } \\
\text { high }\end{array}$ & $\begin{array}{l}\text { Average } \\
\text { Localization } \\
\text { score is less }\end{array}$ \\
\hline
\end{tabular}

* Results reported in the database Messidor-2

Table- II: Unsupervised learning Techniques to diagnose DR

\begin{tabular}{|c|c|c|c|c|c|c|c|c|c|}
\hline \multirow{2}{*}{$\begin{array}{l}\text { Authors/ } \\
\text { Referenc } \\
\text { e }\end{array}$} & \multirow[b]{2}{*}{ Approach } & \multirow[b]{2}{*}{ Data Set } & \multirow[b]{2}{*}{ Classification } & \multirow{2}{*}{$\begin{array}{l}\text { Classification } \\
\text { Parameters }\end{array}$} & \multicolumn{3}{|c|}{ Performance Measures } & \multirow[b]{2}{*}{ Merits } & \multirow[b]{2}{*}{ Demerits } \\
\hline & & & & & Specificity & Sensitivity & $\begin{array}{l}\text { Accurac } \\
\mathrm{y}\end{array}$ & & \\
\hline $\begin{array}{l}\text { Akara } \\
\text { Sopharak } \\
{[1], 2009}\end{array}$ & $\begin{array}{l}\text { Fuzzy C- } \\
\text { means } \\
\text { Clustering }\end{array}$ & $\begin{array}{l}\text { non- } \\
\text { mydriatic } \\
\text { retinal } \\
\text { camera } \\
\text { images } \\
\end{array}$ & $\begin{array}{l}\text { 1. DR } \\
\text { 2. Non-DR }\end{array}$ & Exudates & 99.24 & 87.28 & - & $\begin{array}{l}\text { Improved } \\
\text { execution speed }\end{array}$ & $\begin{array}{l}\text { Considers } \\
\text { only exudates } \\
\text { feature. }\end{array}$ \\
\hline $\begin{array}{l}\text { Carla } \\
\text { Agurto } \\
{[2], 2010}\end{array}$ & $\begin{array}{l}\text { Multiscale } \\
\text { Amplitude- } \\
\text { modulation- } \\
\text { frequency- } \\
\text { modulation } \\
\text { (AM-FM) } \\
\text { \& K-Means } \\
\text { Cluster }\end{array}$ & $\begin{array}{l}\text { Messidor } \\
\& \\
\text { ETDRS } \\
\text { database }\end{array}$ & $\begin{array}{l}\text { 1. Normal and } \\
\text { 2. Pathological } \\
\text { retinal images }\end{array}$ & $\begin{array}{l}\text { Characterizatio } \\
\mathrm{n} \text { of retinal } \\
\text { structures }\end{array}$ & 0.71 & 0.97 & - & $\begin{array}{l}\text { It considers only } \\
\text { global } \\
\text { classification of } \\
\text { images without } \\
\text { having explicitly } \\
\text { trained database } \\
\text { which infers } \\
\text { annotation of } \\
\text { each lesion. }\end{array}$ & $\begin{array}{l}\text { Does not } \\
\text { consider } \\
\text { different } \\
\text { classification } \\
\text { of DR }\end{array}$ \\
\hline $\begin{array}{l}\text { Anupama. } \\
{[6], 2017}\end{array}$ & $\begin{array}{l}\text { Hessian } \\
\text { Matrix \& } \\
\text { Kmeans } \\
\text { clustering }\end{array}$ & $\begin{array}{l}\text { Retinal } \\
\text { images }\end{array}$ & $\begin{array}{l}\text { 1. DR } \\
\text { 2. Non-DR }\end{array}$ & $\begin{array}{l}\text { Blood Vessel } \\
\text { Segmentation }\end{array}$ & $98 \%$ & $84 \%$ & $96 \%$ & $\begin{array}{l}\text { Improved } \\
\text { performance }\end{array}$ & $\begin{array}{l}\text { Minimal } \\
\text { feature } \\
\text { consideration }\end{array}$ \\
\hline
\end{tabular}




\section{RESULTS AND DISCUSSIONS}

The proposed model given in figure 3 considers the retina as the base for classification of DR and prediction of other disorders like stroke, chronic heart disease, renal dysfunction, cardiovascular mortality. current standards for cardio vascular disease mortality screening requires numerous multivariate derived from blood samples, age, gender, smoking status, hypertension, body mass index, glucose, and cholesterol levels [10]. Most cardio vascular risk calculators use some aggregation of these variants to determine patients at the risk of experiencing either a major cardiovascular event or cardiac-related mortality within a pre-determined period of time.

It can be hypothesized that hemorrhages, hard exudates, and micro aneurysms combined with hypertension indicate hefty association with heart failure, stroke, renal non function and cardiovascular risk [12].

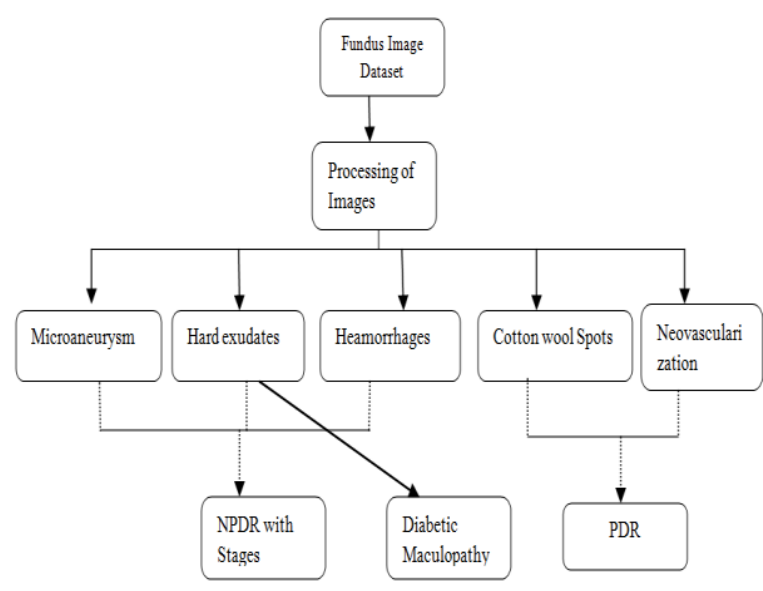

Fig. 3. Proposed Model for classification of DR

\section{CONCLUSION}

The proposed model considers features to be extracted from fundus image for the diagnosis of DR with different classification. So feature selection and extraction must be carefully defined and when combined with hypertension give the association with many other disorders namely Stroke, Congestive Heart Failure and Cardiovascular Risk. It eliminates the need of many preliminary tests and provides complete predictions of disorders to be referable or not.

The future scope includes the implementation of the model using $\mathrm{CNN}$ for feature selection as it considers many parameters and the suitable classifier for offline must be analyzed for time and performance efficiency.

\section{REFERENCES}

1. Akara Sopharak 1, Bunyarit Uyyanonvara and Sarah Barman, "Automatic Exudate Detection from Non-dilated Diabetic Retinopathy Retinal Images Using Fuzzy C-means Clustering”, Sensors 2009, 2148-2161, doi:10.3390/s90302148.

2. Carla Agurto, Victor Murray, Eduardo Barriga, Sergio Murillo, Marios Pattichis, Herbert Davis, Stephen Russell, Michael Abràmoff and Peter Soliz, "Multiscale AM-FM Methods for DiabeticRetinopathy Lesion Detection", IEEE Transactions On Medical Imaging, Vol. 29, No. 2, February 2010,pp.502-512
3. Handayani Tjandrasa, Ricky Eka Putra, Arya Yudhi Wijaya and Isye Arieshanti, "Classification of Non-Proliferative Diabetic Retinopathy Based on Hard Exudates Using Soft Margin SVM", 2013 IEEE International Conference on Control System, Computing and Engineering, 29 Nov. - 1 Dec. 2013, Penang, Malaysia,pp.376-380

4. Jayant Yadav, Manish Sharma and Vikas Saxena, "Diabetic Retinopathy Detection using feedforwardNeural Network, “ 2017 IEEE Proceedings of 2017 Tenth International Conference on Contemporary Computing ( IC3), 10-12 August 2017, Noida, India.

5. Shuang Yu, Di Xiao and Yogesan Kanagasingam, "Exudate Detection for Diabetic Retinopathy With Convolutional Neural Networks", 2017 IEEE 39th Annual International Conference of the IEEE Engineering in Medicine and Biology Society (EMBC),pp. 1744-1747

6. Anupama. P and Dr Suvarna Nandyal, "Blood Vessel Segmentation using Hessian Matrix for Diabetic Retinopathy Detection”, 2017 Second International Conference on Electrical, Computer and Communication Technologies (ICECCT).

7. Devvi Sarwinda, Titin Siswantining, Alhadi Bustamam, " Classification of Diabetic Retinopathy Stages using Histogram of Oriented Gradients and hallow Learning," 2018 IEEE International Conference on Computer, Control, Informatics and its Applications, pp. 83-87.

8. Maroof Ahmad, Nikhil Kasukurthi, Harshit Pande, "Deep Learning For Weak Supervision Of Diabetic Retinopathy Abnormalities", 2019 IEEE 16th International Symposium on Biomedical Imaging (ISBI 2019) Venice, Italy, April 8-11, 2019,pp 573-577.

9. Dinial Utami Nurul Qomariah, Handayani Tjandrasa, and Chastine Fatichah, "Classification of Diabetic Retinopathy and Normal Retinal Images using CNN and SVM",, 12th International Conference on Information \& Communication Technology and System (ICTS) 2019, pp. 152-157.

10. Ryan Poplin, Avinash V. Varadarajan, Katy Blumer, Yun Liu, Michael V. McConnell, Greg S. Corrado,Lily Peng and Dale R. Webster," Predicting Cardiovascular Risk Factors from Retinal Fundus Photographs using Deep Learning", Cornell University, arix.org.

11. A K Kurana , "Comprehensive Ophthalmology", $6^{\text {th }}$ Edition

\section{AUTHORS PROFILE}
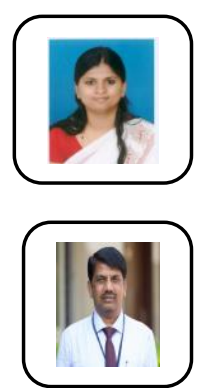

Manjula $\mathbf{L}$ is a Research Scholar at RNSIT. She earned Mtech and BE in Computer Science and Engineering from Visvesvaraya Technological University. Her research interests are Machine Learning, Artificial Intelligence, Internet of Things and Ophthalmology.

Dr G T Raju currently working as Vice-Principal and Head of CSE Dept. RNSIT. He has 25+ years of teaching and $12+$ years of research experience. He has published 55 papers in international Journals, conferences. He has organized 28 workshops/FDP/conferences \& delivered 30 invited talks. He has received 21 lakhs research grants from AICTE and VTU. He is life member of ISTE and CSI. His research interests are pattern recognitions, web mining, image processing \& information retrieval, machine learning and artificial intelligence. He has held various positions at university 